Article

\title{
Greenhouse Gas and Air Pollutant Emissions of China's Residential Sector: The Importance of Considering Energy Transition
}

\author{
Rui Xing *, Tatsuya Hanaoka, Yuko Kanamori and Toshihiko Masui \\ Center for Social and Environmental Systems Research, National Institute for Environmental Studies, 16-2, \\ Onogawa, Tsukuba, Ibaraki 305-8506, Japan; hanaoka@nies.go.jp (T.H.); kanamori@nies.go.jp (Y.K.); \\ masui@nies.go.jp (T.M.) \\ * Correspondence: xing.rui@nies.go.jp; Tel./Fax: +81-29-850-2955
}

Academic Editor: Avi Friedman

Received: 9 March 2017; Accepted: 11 April 2017; Published: 14 April 2017

\begin{abstract}
This study focuses on China's residential sector and examines energy use growth resulting from income increases and urbanization development. We also look at the energy transition (from primitive fuels to advanced fuels) caused by economic development, as well as the mitigation potential of greenhouse gas and air pollutants emissions. Several studies have provided evidence of a positive correlation between income and per capita final energy use at the national level. In addition to income, demographic factors such as household size and education level have also been suggested to have influences on urban energy use. In this study, we consider various socio-economic indicators to analyze their influences on household energy use. Considering the economic and climate diversity across China's provincial regions, our analysis is based on the 31 provincial regions and examines the emissions pathways of 31 provincial regions. We first apply a multiple linear regression analysis on historical panel data to determine the correlations between socio-economic indicators and domestic energy sources. Next, we use the Asia-Pacific Integrated Model (AIM/Enduse) to estimate mitigation potential due to energy transition and sustainable policies. The results suggest that income and education levels are major drivers that have a significant impact on household energy choices both in rural and urban areas. In rural areas, climate and energy resource potential also have an impact on the choices of biomass energy use. Without consideration of energy transition constraints, future estimation of energy consumption and carbon dioxide $\left(\mathrm{CO}_{2}\right)$ emissions can be greatly overestimated or underestimated depending on the socioeconomic status of the province. It is important to note that the way that we consider energy transition constraints also significantly affects the air pollutants' emissions of the household sector due to biomass consumption, especially on particulate matter 2.5 microns or less $\left(\mathrm{PM}_{2.5}\right)$ emissions. Furthermore, implementation of efficient technologies contributes to achieving China's Intended Nationally Determined Contribution (INDC) and brings the co-benefits of air pollutants' emission reductions.
\end{abstract}

Keywords: household energy; energy ladder; INDC; scenario analysis; Chinese provinces

\section{Introduction}

In final energy consumption, the building sector is one of the largest energy-consuming sectors, accounting for over one-third globally and is an equally important source of carbon dioxide emissions. From 2000 to 2010, the residential sector consumption increased from 282,966 kilotonnes of oil equivalent (ktoe) to 360,595 (ktoe) [1] in China, driven by rapid growth in the number of households, residential floor area and higher ownership rates of energy consuming domestic devices. Implementation of energy efficient technologies is needed to address sustainability in the household 
sector without changing the comfort levels. The energy choice of households is crucial to the technology selection. Low-carbon technologies are usually based on advanced energy sources. In an area with limited access to commercial energy resources, low-carbon technologies will be difficult to implement in households. This study looks into the energy transition process and its constraints caused by socioeconomic development, as well as the mitigation potential of carbon emissions in China's household sector.

Several existing studies suggested two types of energy transition models in the residential sector-the energy ladder and energy stack ([2]; Figure 1a). The energy ladder theory assumes that households will move to more sophisticated energy carriers as their income increases. On the other hand, the energy stack argues that household energy transition does not simply move from one energy source to another. With increasing income, households instead adopt multiple fuel choices and sometimes users may switch back to traditional biomass even after adopting modern energy carriers.

This study is based on the energy stack theory, which assumes that, in China's urban areas, household energy switches from transition fuel to advanced fuels. The rural energy stack has one more layer than the urban stack where household energy carriers start at primitive fuels and switch to transition fuels, and then move further to advanced fuels. Figure $1 \mathrm{~b}$ indicates the scope of energy carriers in this study, though there are some caveats. Firstly, natural gas is a major energy carrier in urban households and is widely used for cooking and hot water applications. However, the distribution of the natural gas network basically depends on available city infrastructure rather than choices of households. Therefore, the transition process of natural gas is not analyzed in this study. Next, there has been some controversy regarding the gap of energy balance statistics about oil products between International Energy Agency (IEA) publications and Chinese yearbooks [3]. The Chinese yearbooks recorded a certain amount of gasoline use in the residential sector while the IEA database indicated that there is no gasoline use and a rather small usage of diesel in this sector. Scientists from Lawrence Berkeley National Laboratory (Berkeley, CA, USA) out this problem [4] and suggested that the Chinese yearbooks might include some energy consumption of household vehicles as "residential" use. Household consumption of kerosene is contrastingly inconsistent; it appeared in the IEA database but was not included in the Chinese yearbooks. So far, there is no concrete conclusion over this issue and this paper does not look into the transition process of gasoline and kerosene while analyzing energy stack theory. Both Chinese yearbooks and IEA publications indicate that diesel oil use in the residential sector is quite small (less than $0.5 \%$ during the past decade); therefore, it is excluded from the study subjects, as is biogas in rural households for the same reason.

While analyzing the energy transition process, this study concentrates on five energy sources (firewood, stalks (In China, stalks are by-products of cereal plants and mainly from dry stalks of Asian rice, wheat and corn.), coal, liquid petroleum gas (LPG), electricity) in rural households and three energy sources (coal, electricity, LPG) in urban households.

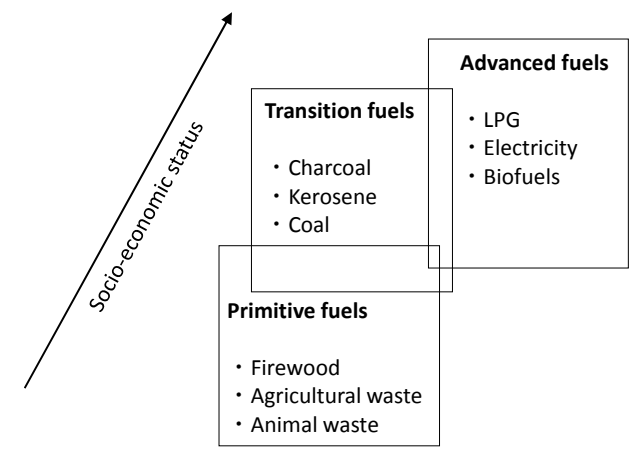

(a)

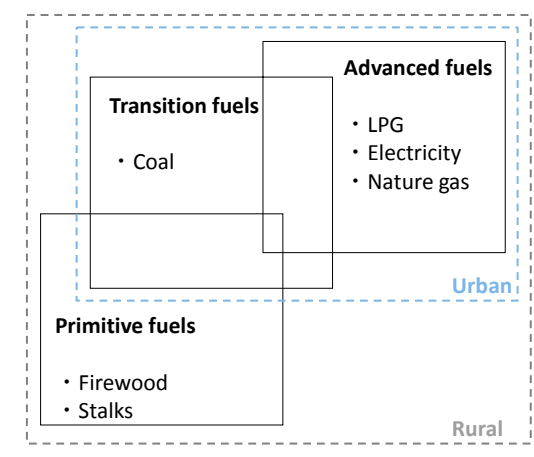

(b)

Figure 1. (a) The energy stack theory in general; (b) the assumed household energy stacks in this study. 
Several studies have identified the socioeconomic driving forces of energy choice behaviour. Education is seen as an important determinant of the energy transition process. Barnes et al. [5] and Peng et al. [6] suggested that higher levels of education cause households to use less traditional biomass fuels (i.e., primitive fuels) in several developing countries including China. Many researchers have also found availability of household labour as a determining factor for use of traditional biomass fuel in rural areas. The household fuel choice also involves a gender perspective. Gupta et al. [7], Sathaye et al. [8], and Israel et al. [9] looked into energy use in several Asian countries and Bolivia and found that households with more women present have a larger availability of firewood resources. Heltberg et al. [10] revealed that, in Guatemala, the female population share in households is assumed to particularly constrain a switch to modern fuels as "... they (women) are mainly responsible for the collection of firewood". Additionally, women's income is considered to be an important determinant of modern fuel choice.

Some studies of household energy use in Mexico and African countries [11-13] suggest that energy transition is not unidirectional and people may switch back to traditional biomass when a high increase of modern energy prices occurs. However, the effect of fuel prices on fuel choice is still under debate. Some scholars suggest that prices are the main factor restricting households to move to modern fuels in Sri Lanka and Tanzania [14,15], while others find fuel prices have little impact on household fuel selection in Botswana [16]. Income level is another monetary factor that effects energy transition. In studies [7,17-19] on households of India, Zimbabwe and South Africa, energy choice is found to progress towards modern energy when income level increases. An interesting finding in rural China is that traditional biomass use will rise as income level increases [20]. This is contrary to the proposed energy transition theory. Researchers suggested that the possible reason is that the basic energy demand has not been fully met in rural regions. Furthermore, in rural areas, there is a lack of proper infrastructure to deliver the advanced energy sources.

In this study, we firstly select socio-economic indicators that potentially affect the household transition process and analyse their co-relations with household energy choice. Next, the future household-related $\mathrm{CO}_{2}$ and air pollutant emissions and reduction potentials are estimated by using the integrated assessment model (AIM/Enduse [21,22]) while considering the impact of the energy transition process on household energy shares. The results will provide estimations of household energy share in the future and emission reduction potential due to socio-economic development. This study can contribute to the existing studies in the following two aspects. One aspect is that most of the integrated assessment models do not consider the energy transition process in the rural/urban household sector at provincial levels in China while generating emission pathways. This may cause overestimation or underestimation of the emission reduction potential. This study will provide an energy share estimation of the household sector in the future and a more probable emission reduction potential evaluation. Another aspect is that adopting a universal low-carbon technology in different regions is not effective due to socioeconomic gaps across regions such as different climate zones and different levels of economic development. This study will provide tailored implementation plans for low-carbon technologies for regions at various socioeconomic statuses.

This paper is structured into Sections 2-4. Section 2 describes the methodology for estimating household energy share and $\mathrm{CO}_{2}$ emissions. Section 3 presents the estimation results. Section 4 summarizes key conclusions and future work.

\section{Methods}

\subsection{Study Subjects and Regional Approach}

There are 31 provincial-level administrative regions in mainland China. The climate in China varies widely, ranging from tropical regions in the south to subarctic areas in the north. China's climactic divide separates the country into northern (central heating) and southern (no central heating) regions, while its economic divide separates it into eastern and western regions (Figure 2). In order 
to take full consideration of the above-mentioned climatic and economic disparity, in the previous studies, we have carried out emission evaluation studies on a regional basis [23]. Several existing studies have pointed out that economic indicators such as income and per capita GDP are principal drivers of household energy choice. In a relatively more developed region, the share of commercial energy appears to be higher than other less developed regions. In addition, climate also has an impact on household energy share. In cold areas, heating service supported by coal is currently the major application of energy use, while in warm areas, people consume more energy through the use of electronic appliances. Under such circumstances, the analysis of household energy share is also conducted on a regional basis and efficient technology evaluations are tailored for regions at various socioeconomic statuses.
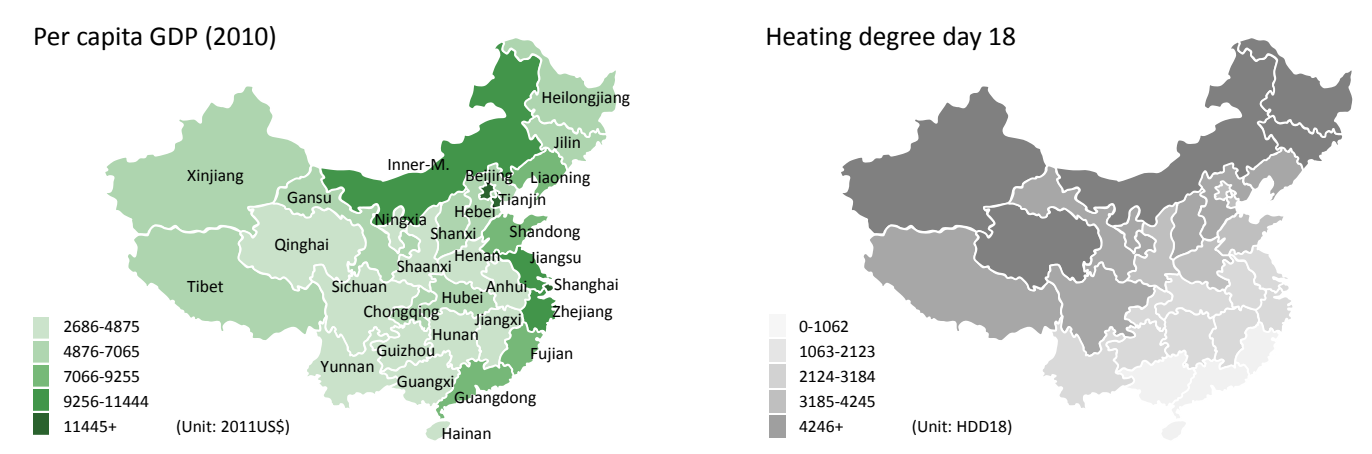

Figure 2. Regional gaps in 31 Chinese regions.

\subsection{Energy Transiton Model}

\subsubsection{Regression Analysis Based on Historical Panel Data}

In our energy transition model, socioeconomic indicators such as income and education levels are considered as input parameters (explanatory variables) and maximum shares of energy sources are the model's output results. Several studies have looked into the impact of socioeconomic indicators on household energy choices and concluded that the mechanism is complex and varies from country to country. We thoroughly examined various socioeconomic indicators and selected certain ones as explanatory variables of the energy transition model. There are three stages during the indicator selection. The first stage is based on a review study carried out by Van der Kroon et al. [2]. The authors reviewed seven previous studies and identified 34 driving forces underlying energy choice behavior. The 34 indicators fall into three categories that represent the socioeconomic status of households such as household opportunity set, external decision context and external environment. The study subjects of the seven studies are India and several African countries but do not include China. Considering China's circumstances, we excluded some unnecessary indicators such as cultural background and food preferences (based on the religion of the household head).

Data availability is another important criterion of indicator selection. Our study is conducted on a regional basis, and, for some indicators, the data are difficult to collect and predict for each Chinese province. Due to such reasons, we first selected the following five socioeconomic indicators to test their co-relationship with energy choices: income, education, household size, age and gender. Previous studies $[12,24]$ suggested that increasing availability of household labor could be a determining factor especially for biomass use in rural areas. Therefore, in this study, the age indicator is further interpreted into dependency (The definition of "dependency" is given in Chinese yearbooks.) - population ages under 14 and above 65 divided by population ages between 15 and 64 in order to describe share of household labor. The number of women in a household and women's income are two major gender findings that constrain a switch to modern fuels [7-10]. Due to lack of statistics on regional women's income in China, here we refer the gender indicator to the number of women in one household. We then collected the panel data (Table A1) of the energy use and five selected indicators in 31 regions 
to conduct the multiple regression analysis by using the least squares method. The time period of the panel data is from 2000 to 2007 (From 2008, the Chinese Yearbook stopped tallying energy use of biomass (firewood and stalks)) Equation (1) is the regression equation:

$$
S_{e, r, t}=\sum_{i} a_{i, e} X_{i, r, t}+b_{e},
$$

where $e$ is energy type; $r$ is region; $t$ is year; $i$ is explanatory variable; $S$ is energy share; $a_{i, e}$ is regression coefficients; $X_{i, r, t}$ is value of explanatory variable; and $b_{e}$ is regression intercept.

From the results of the first stage, we found that most energy choices in households are influenced by income and education levels at a determination coefficient around 0.8 in urban areas. However, determination coefficients of rural coal and biomass appeared to be quite low (above 0.5) at this point. Unlike the urban areas, coal and biomass in rural areas are often sourced from the local areas. Thus, in the second stage, energy resource indicators including production shares (of national total) of coal, cereal and timber were added into the regression analysis. As a result, production share of cereal and timber show a high co-relationship with energy use of stalks and firewood, respectively. However, a co-relation between coal use ad local production share was not observed. Furthermore, the results didn't improve even after we introduced a dummy variable of coal production (" 1 " if more than $3 \%$ of national total, " 0 " if not).

In order to better model coal use in rural households, we looked into the energy use supported by coal and found out that over $80 \%$ of coal consumption was used for heating in rural households [25-29]. In the third and final stage of energy transition modeling, we add climate and housing indicators as explanatory variables to conduct a more comprehension regression analysis. Climate indicators include heating degree-day 18 (HDD18) and a dummy variable (HDD dummy, " 1 " if central heated " 0 " if not), which represent the impacts from climate and central heating systems, respectively. Housing indicators specifically refer to per capita floor area, which examines the impact of heating demand (heated floor area). In the third stage, there are 12 explanatory variables provided for the regression analysis. Among those 12 variables, it is possible that some are co-related. For instance, education level is usually influenced by income level. Conducting regression analyses on those variables may face the risk of multicollinearity and hence effect the reliability of the results. As a solution, the 12 selected variables are divided into seven perspectives. The variables in the same perspective are at high risk of multicollinearity and only one variable from each perspective is used to perform a regression analysis at one time. We test all variable combinations from seven perspectives and take combinations that have the highest determination coefficients as final results. Table 1 summarizes the grouping of perspectives and definitions influencing variables $(X)$.

Table 1. Perspectives and explanatory variables.

\begin{tabular}{|c|c|c|}
\hline Perspective & Explanatory Variable & Definition \\
\hline \multirow{2}{*}{ Development } & Income (2011\$US) & - \\
\hline & Education (\%) & Educated in college and higher level \\
\hline \multirow{2}{*}{ Climate } & $\begin{array}{l}\text { Heating degree-day } 18 \\
\text { (HDD18) dummy }\end{array}$ & " 1 " if central heated, " 0 " if not \\
\hline & HDD18 & $\begin{array}{l}\text { The number of degrees that a day's average temperature is below } 18 \text { degree } \\
\text { Celsius (the temperature below which buildings need to be heated) }\end{array}$ \\
\hline Household & Household size & Persons per household \\
\hline Housing & Per capita floor area $\left(\mathrm{m}^{2}\right)$ & - \\
\hline Age & Dependency & (Age $0-14+$ Age 65 and over)/Age 15-64 \\
\hline \multirow{4}{*}{ Energy resource } & Cereal production share & Provincial production/national total \\
\hline & Timber production share & Provincial production/national total \\
\hline & Coal production share & Provincial production/national total \\
\hline & Coal production dummy & " 1 " if more than $3 \%$ of national total, " 0 " if not \\
\hline Gender & Female share & Female population per household \\
\hline
\end{tabular}




\subsubsection{Estimating Future Energy Share}

According to regression analysis results, out of 12 proposed variables, eight show co-relationships with household energy choices, and they are used to constrain the future energy share. Future urban and rural income levels are disaggregated from Shared Socioeconomic Pathways [30,31]. Education level and household size are extrapolated based on statistic panel data. Dependency is calculated using a regional cohort model we developed in a previous study [32]. HDD18 and production shares of cereal and timber are taken from statistical data of the base year and the values are set as constant through the future estimation period. A dummy coefficient is added to Equation (1) in order to calibrate the estimates with statistical data of the base year (2007). Equation (2) describes the energy transition model that estimates maximum energy shares in the future.

$$
S_{e, r, t}=\sum_{i} a_{i, e} X_{i, r, t}+b_{e}+d_{e, r}
$$

where $d_{e, r}$ is base year calibration coefficient.

\subsection{Greenhouse and Air Pollutant Gas Emissions}

In order to estimate greenhouse and air pollutant gas emissions, we use the AIM/Enduse model, which is a bottom-up type linear optimization model with a detailed technology selection framework. The model distributes total energy service demand to secondary energy sources and calculated gas emissions based on emission factors of each energy source. Both direct and indirect gas emissions are considered emissions from the residential sector in this study. Under our definition, indirect emissions are attributed to residential electricity and heat consumption. Secondary energy production from each primary energy source is taken from the IEA's projections [33]. According to the IEA's Current Policy (CP) Scenario, energy efficiency in China's power sector can be improved in the future. In the IEA's CP scenario, electricity production from coal decreases from $77 \%$ in 2010 to $62 \%$ in 2030 . Meanwhile, the primary energy share of gas and nuclear energy in the power sector increases by a wide margin over the same period (Table A2). Air-pollution-removal technologies have been gradually adopted in the electricity and heat generation sectors over the past decades [34]. As a consequence, the future emission factors mostly tend to decrease in line with the historical trend in the electricity and heat generation sectors.

The present emission factors for coal, oil products, natural gas, and biofuel are considered based on various inventory guidelines [35-37] and peer-reviewed papers [38-45]. In this research, we used the Shared Socioeconomic Pathways (SSPs; [30]), a set of qualitative and quantitative narratives that describe future socioeconomic conditions to identify socioeconomic indicators. Each SSP describes a different future socioeconomic scenario. Estimation of future emission factors are based on SSP2-the "Middle of the road" storyline that describes the world as "business as usual" and expects common trends in recent decades to continue, with some progress toward achieving development goals. In SSP2, we assume that the current legislative policies towards air pollution and future emissions trends will stay in line with the historical trend. Thus, the future emission factors in this study are set to gradually or slightly decrease in tandem with the historical policy implementation towards air pollutants seen in the emissions inventory by REAS (Regional Emission Inventory in Asia). The assumed emission factors for black carbon (BC), $\mathrm{PM}_{2.5}$, and Sulfur dioxide $\left(\mathrm{SO}_{2}\right)$ in this study all decreased through the past decades. To "continue the past trend," this study also sets the emission factors for the three gases at progressively lower levels in the future. Table 2 summarizes emission factor estimates of the four gases covered for electricity and heat in this study. 
Table 2. Emission factors for electricity and heat (China) Unit: $t$ /toe.

\begin{tabular}{ccccc}
\hline \multirow{2}{*}{ Electricity } & Gas & $\mathbf{2 0 1 0}$ & $\mathbf{2 0 2 0}$ & $\mathbf{2 0 3 0}$ \\
& & & & \\
& Carbon dioxide & 3.1076 & 2.6759 & 2.5797 \\
& Particulate matter 2.5 & 0.0004 & 0.0004 & 0.0004 \\
\hline Heat & & & \\
& Carbon dioxide & 3.8307 & 3.8307 & 3.8307 \\
& Particulate matter 2.5 & 0.0007 & 0.0007 & 0.0006 \\
\hline
\end{tabular}

\subsection{Scenario Setting}

For the model simulation, we prepare four scenarios to evaluate the gas emission growth and reduction potential: the Fix (FIX), Reference without considering energy transition constraints (REF wo.ET), Reference with considering energy transition constraints (REF w.ET), and Intended Nationally Determined Contributions with considering energy transition constraints (INDC w.ET) scenarios. In the FIX scenario, the technologies can be regarded as frozen: the technology levels and their shares remain at the base year (2010) level and no efficient technologies are implemented in the future. Thus, FIX is designed to offer one of the future pictures of how gas emissions will increase without considering any additional efficient technology intervention. In the REF scenario, efficient technologies stored in technology databases in the AIM/Enduse model are allowed to be selected in the future market without any carbon tax or carbon policy under the linear optimization framework. Traditional technologies compete with efficient technologies over cost-effectiveness, but no carbon pricing is imposed; thus, it describes an autonomous energy efficiency improvement process for efficient technologies. The REF wo.ET scenario sets no constraint on the energy transition described in Section 2.2. In contrast, the REF w.ET scenario sets the maximum share of each energy source determined by Equation (1). Energy share ranges from zero to one, thus values that fall outside of the range will be corrected to the limit value (i.e., zero or one). By comparing results between the REF wo.ET scenario and the REF w.ET scenario, it is possible to discuss the significance of considering energy transition constraints while discussing emission profiles of $\mathrm{CO}_{2}$ and air pollutants. The INDC w.ET scenario sets the residential $\mathrm{CO}_{2}$ emissions per unit of GDP in 2030 at $60 \%$ lower than the 2005 level. This emissions cap refers to one of the actions in China's INDC [46]. According to the figures for 2005 in the IEA statistics, the residential sector contributed $6 \%$ of the total $\mathrm{CO}_{2}$ emissions $[47,48]$, and the $\mathrm{CO}_{2}$ emissions intensity stood at $0.8 \mathrm{~kg} / \mathrm{US} \$$ [49]. Previous studies show that the share of residential $\mathrm{CO}_{2}$ emission in China has been maintained at a stable level since 2000 and will not change significantly in the next few decades $[4,50]$. Therefore, the INDC w.ET scenario sets the residential $\mathrm{CO}_{2}$ emissions share at the same level as 2005 while setting the $\mathrm{CO}_{2}$ emissions intensity at $0.016 \mathrm{~kg} / \mathrm{US} \$$, a level that will enable China to realize the $60 \%$ reduction target in the residential sector proposed in its INDC. Table 3 summarizes the definitions of the three scenarios.

Table 3. Scenario overviews.

\begin{tabular}{ll}
\hline \multicolumn{1}{c}{ Scenario Name } & \multicolumn{1}{c}{ Scenario Descriptions } \\
\hline FIX & $\begin{array}{l}\text { The level of future technology efficiency and diffusion ratio are } \\
\text { fixed as the same as the base year (i.e., the 2010 level). }\end{array}$ \\
\hline & $\begin{array}{l}\text { Efficient technologies autonomously penetrate the future } \\
\text { market under no carbon tax or carbon policy. }\end{array}$ \\
Reference without considering energy \\
transition constraints
\end{tabular}


Table 3. Cont.

\begin{tabular}{ll}
\hline \multicolumn{1}{c}{ Scenario Name } & \multicolumn{1}{c}{ Scenario Descriptions } \\
\hline $\begin{array}{l}\text { Reference with considering energy } \\
\text { transition constraints }\end{array}$ & $\begin{array}{l}\text { Efficient technologies autonomously penetrate the future } \\
\text { market under no carbon tax or carbon policy. } \\
\text { The model will consider energy transition constraints and } \\
\text { select a share of each energy source so as not to exceed the } \\
\text { maximum value estimated in Section } 2.2 .\end{array}$ \\
\hline \multirow{2}{*}{$\begin{array}{l}\text { Intended Nationally Determined } \\
\text { Contributions with considering energy } \\
\text { transition constraints }\end{array}$} & $\begin{array}{l}\text { Efficient technologies penetrate the future market to achieve } \\
\text { the emission level, which is determined by China's INDC. } \\
\end{array}$ \\
& $\begin{array}{l}\text { The model will consider energy transition constraints and } \\
\text { select share of each energy source so as not to exceed the } \\
\text { maximum value estimated in Section 2.2. }\end{array}$ \\
\hline
\end{tabular}

\section{Results}

\subsection{Constraints on Future Household Energy Share}

Table 4 shows the coefficients of explanatory variables $\left(a_{i, e}\right.$ in Equation (1)) resulted from regression analysis. Income and education are two major drivers of energy transition in the residential sector as they are co-related with multiple energy shares. Furthermore, previous studies pointed out that female share in households has an impact on household energy choice in India and several African countries. However, this co-relation is not observed in our study on the Chinese households.

Table 4. Coefficients of explanatory variables ( $\mathrm{U}=\mathrm{Urban} ; \mathrm{R}=\mathrm{Rural})$.

\begin{tabular}{|c|c|c|c|c|c|c|c|c|c|}
\hline \multirow[t]{2}{*}{ Perspective } & \multirow[t]{2}{*}{ Explanatory Variable } & \multirow{2}{*}{$\begin{array}{c}\text { Stalks } \\
\mathrm{R}\end{array}$} & \multirow{2}{*}{$\frac{\text { Firewood }}{\mathrm{R}}$} & \multicolumn{2}{|c|}{ Coal } & \multicolumn{2}{|c|}{ LPG } & \multicolumn{2}{|c|}{ Electricity } \\
\hline & & & & $\mathrm{U}$ & $\mathrm{R}$ & $\mathrm{U}$ & $\mathrm{R}$ & $\mathrm{U}$ & $\mathrm{R}$ \\
\hline \multirow{2}{*}{ Development } & Income (2011\$US) & & 0.0002 & 0.0002 & & 0.0002 & 0.00008 & 0.36 & 0.0001 \\
\hline & Education (\%) & 4.85 & & & 9.08 & & & & \\
\hline \multirow{2}{*}{ Climate } & HDD dummy & & & & 0.17 & & & & \\
\hline & HDD18 & 0.00004 & 0.00007 & & & & & & \\
\hline Household & Household size & & & & & 0.34 & & 0.277 & \\
\hline Housing & Per capita floor area $\left(\mathrm{m}^{2}\right)$ & & & & & & & & \\
\hline Age & Dependency & & & & 0.008 & & 0.001 & & 0.0007 \\
\hline \multirow{4}{*}{$\begin{array}{l}\text { Energy } \\
\text { resource }\end{array}$} & Cereal production share & 2.82 & & & & & & & \\
\hline & Timber production share & & 1.39 & & & & & & \\
\hline & Coal production share & & & & & & & & \\
\hline & Coal production dummy & & & & & & & & \\
\hline Gender & Female share & & & & & & & & \\
\hline
\end{tabular}

Figure 3 shows the estimated results of maximum energy share in 31 provinces based on the energy transition model described in Section 2.2. In Figure 3, each color represents one provincial region. Generally, the transition from primitive fuel (i.e., firewood and stalks) to advanced fuel (i.e., LPG and electricity) is observed in both urban and rural areas. For traditional biomass, stalks will still have a certain amount of share in most of the regions while the share of firewood will drop to a limited level. According to regression analysis results in Section 2.2, stalks' share is negatively correlated with education level and firewood is negatively correlated with income. Thus, the larger the increase in the level of education and income is, the larger is the decrease in the level of maximum share of stalk and firewood. However, the level of income increase is expected to be much more drastic than the increase in the education level in the future (see Figure A1). Consequently, the share of firewood drops to a lower level compared to stalks. 


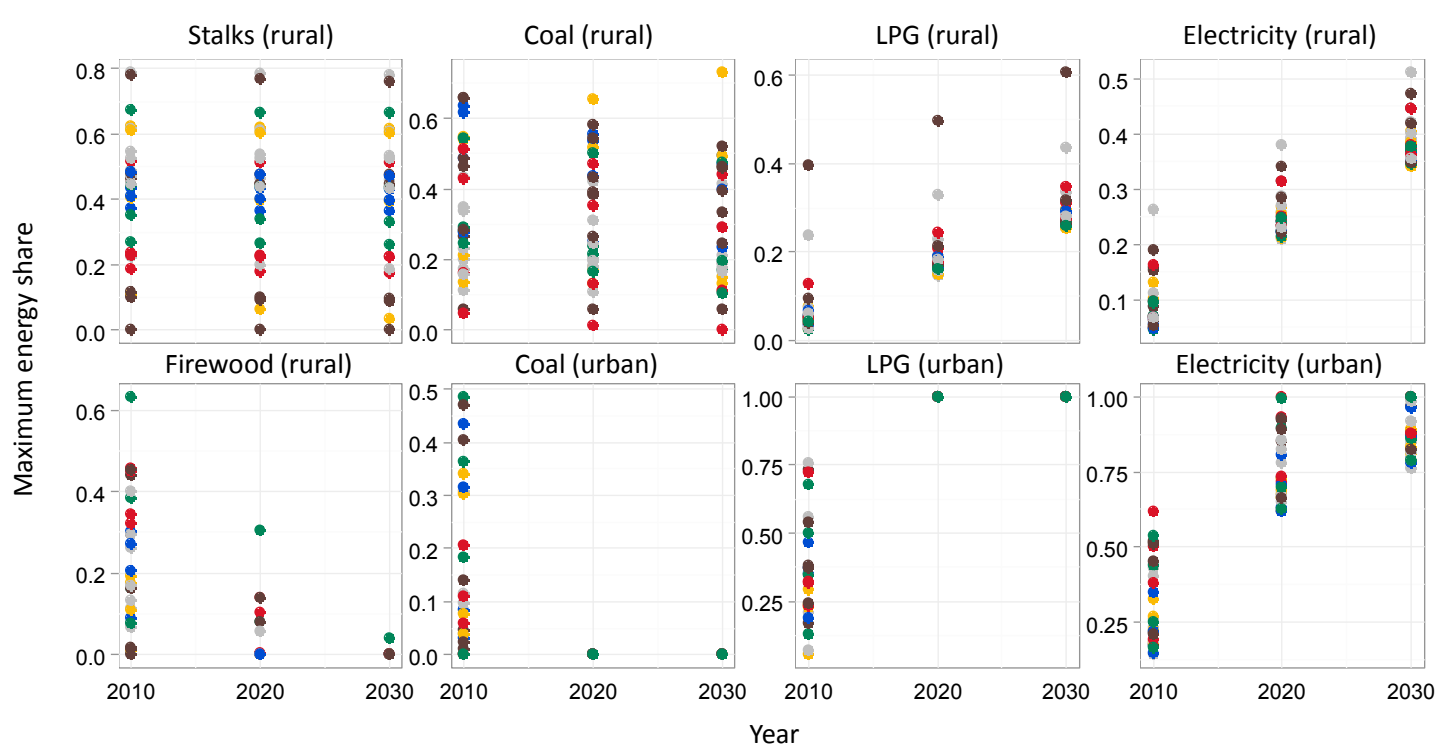

Figure 3. Regional energy shares in 31 Chinese regions.

The similar difference is also overserved in future shares of coal. As the major variables of coal shares in urban and rural households are correlated with income and education level, respectively, coal will be completely phased out in urban areas and its share in rural areas will drop to under $50 \%$ in most of the regions. Urban households will gain $100 \%$ access to advanced fuels LPG and electricity. Shares of LPG and electricity in rural areas will not be as high as the urban levels but will increase through the next 20 years as well due to the increase of income levels.

\subsection{National Energy Consumption}

Figure 4 shows the estimated energy consumption in China's residential sector. In the REF wo.ET scenario where energy transition process and its constraints is not taken into account, coal consumption is overestimated in urban areas and underestimated in rural areas. According to estimates from energy transition models, in China's urban areas, coal will be phased out completely through the next 10 years. Currently, coal is mostly used as an energy source of individual heating, and its role is expected to be replaced by commercial biomass (In this study, "commercial biomass" refers to a newly developed energy source. Basically commercial biomass is produced from traditional biomass (firewood, stalks, etc.). Compared to traditional biomass, it has a much lower emissions factor than $\mathrm{CO}_{2}$ and air pollutants. In addition, it has a commodity value and can be traded in the market, while traditional biomass is considered to be collected by household members directly. A typical commercial biomass in the Chinese energy market can be found on the following webpage [51]). For rural households, coal is an important energy carrier and it shares the second largest energy consumption, just next to traditional biomass. In the REF wo.ET scenario, the use of coal in rural households switches back to traditional biomass due to its lower cost and emission factors. However, this reversed transition is neither realistic nor favorable to a sustainable household energy system. In the REF w.ET scenario, as socioeconomic status climbs to a higher stage, a part of coal, oil products (LPG and diesel oil) and traditional biomass is replaced by commercial biomass while coal still ranks as the second major energy source. Furthermore, affected by the decline of coal and traditional biomass use in both urban and rural areas, commercial biomass is introduced in the REF the w.ET scenario. The share of commercial biomass increases in the INDC w.ET scenario, led by the carbon cap setting. 

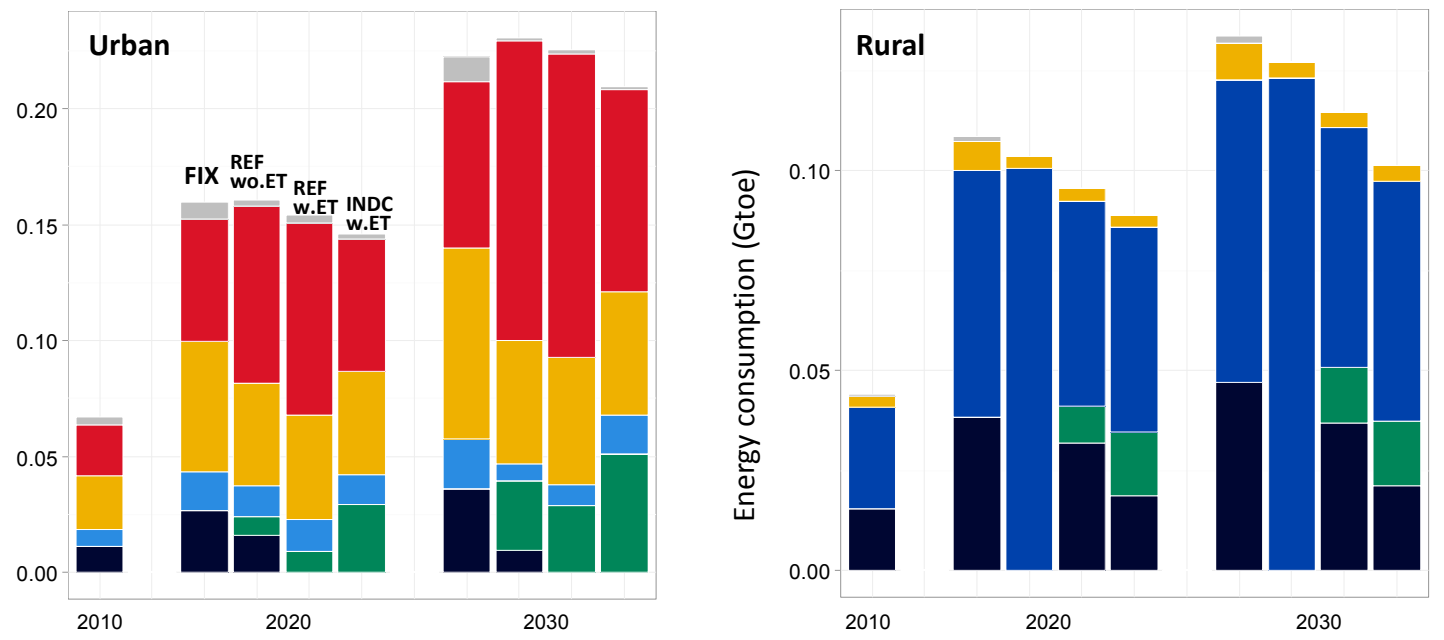

Figure 4. National energy consumption (model projection).

With the carbon cap in INDC w.ET scenario, rural reduction potential is larger than urban, indicating lower reduction costs in rural households. In order to achieve the two-degree target [52], electrification and low carbon electricity are some of the key measures. However, from the results of ref w.ET and INDC w.ET, there is no obvious shift from other energy sources to electricity urban or rural areas due to the high cost of electrification and electric devices. In order to enhance low carbon electrification, it is necessary to promote electrification policies additional to the INDC w.ET scenario. As energy sources climb from primitive fuels to advanced fuels, the device efficiencies will also be improved. This explains why the total energy consumption in the ref w.ET is lower than it is in the ref wo.ET despite the fact that service demand is the same in the two scenarios.

\section{3. $\mathrm{CO}_{2}$ Emissions}

Figure 5 shows the estimated results of $\mathrm{CO}_{2}$ emissions in urban and rural areas. The national results in Figure 5 are an aggregated national total of 31 provincial regions. At the national level, the cost optimization simulation in AIM/Enduse results in the bulk of traditional biomass consumption in rural areas, hence an underestimation of $\mathrm{CO}_{2}$ emissions in the REF wo.ET. The huge emissions gap between REF wo.ET and REF w.ET leads to a conclusion that the energy transition process and its constraints have a significant impact on emissions estimation. To examine the impact of socioeconomic development on energy transition and carbon emissions, we select Beijing and Hebei as two socioeconomic representatives and compare their results. Geographically, Beijing Municipality lies in the center of Hebei province so their climate conditions are similar. Beijing is the capital city of China with a relatively higher socioeconomic status. Currently, per capita GDP in Beijing is more than twice that in Hebei [53]. In urban Beijing, coal will be completely phased out by 2030 and household energy choice will gradually switch to heat and commercial biomass. In rural Beijing, coal remains as the primary $\mathrm{CO}_{2}$ emitter, but energy consumption of coal decreases, which leads to reduction potentials in the INDC w.ET scenario. Compared to Beijing, Hebei has a lower socioeconomic status, which resulted in different energy choices. Urban households in Hebei use more coal and less electricity. Similar to Beijing's projection, coal will be phased out in urban Hebei. However, electricity share will not increase to as high a level as Beijing due to lower income. It is pointed out that income level is one of the barriers of electrification. Compared to FIX, in the INDC w.ET scenario, $\mathrm{CO}_{2}$ emissions in urban Beijing, urban Hebei and rural Hebei reduced by $38 \%, 33 \%$ and $51 \%$ respectively. While rural Beijing is already at a relatively high socioeconomic status, the energy transition model projects that traditional biomass will be completely replaced by coal and other advanced energy sources by 2030. Rural Beijing 
is also an exception where the energy transition process leads to an emissions increase of about $23 \%$ in the INDC w.ET scenario. The optimization simulation is applied on a national level so reduction potentials can be allocated in other rural regions with lower socioeconomic status.

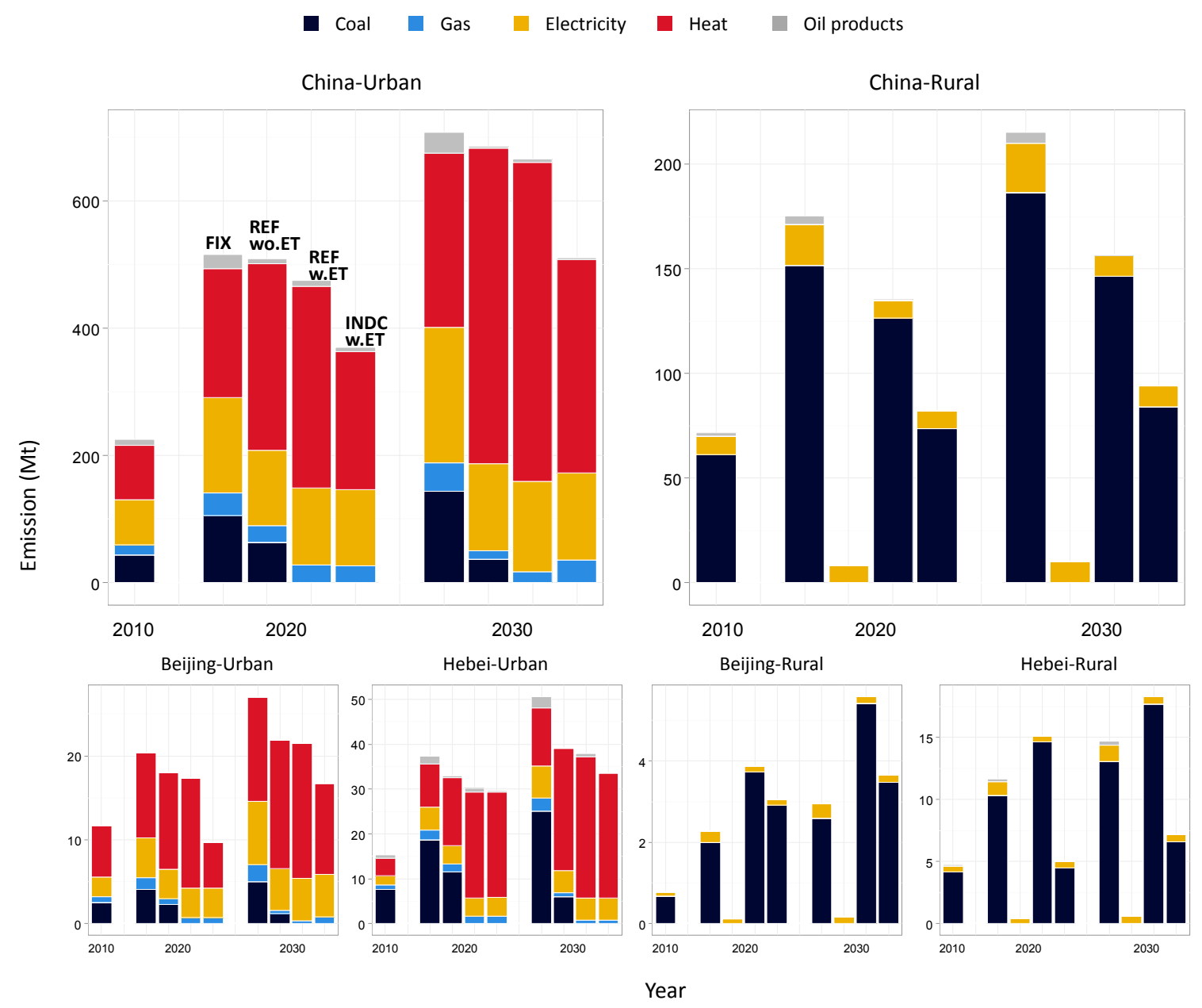

Figure 5. National and regional $\mathrm{CO}_{2}$ emissions (model projection).

\subsection{Particulate Matter 2.5 Microns or Less $\left(P M_{2.5}\right)$ Emissions}

Overestimation or underestimation of a certain energy use not only affects $\mathrm{CO}_{2}$ emissions estimations but also some air-pollutants. Besides $\mathrm{CO}_{2}$ emissions profiles, we also evaluate emissions of black carbon, $\mathrm{PM}_{2.5}$ and sulfur dioxide in the four proposed scenarios, in which $\mathrm{PM}_{2.5}$ emissions estimation has changed the most after introducing the energy transition process. Figure 6 shows the estimated $\mathrm{PM}_{2.5}$ emissions in urban and rural areas. Without consideration of energy transition, $\mathrm{PM}_{2.5}$ emissions will be overestimated in the REF (wo.ET) scenario by including the emissions from coal. The significance of evaluating energy transition process and its constraint is specially reviewed in the rural area's results-as discussed in Section $3.3 \mathrm{CO}_{2}$ emissions can be largely reduced by using the carbon neutral fuel traditional biomass. However, pushing energy transition backwards to tradition biomass will lead to an increase of $\mathrm{PM}_{2.5}$ emissions and therefore bring the risk of non-energy (health) problems. The fact that $\mathrm{PM}_{2.5}$ emissions decrease considerably in the INDC w.ET scenario in both urban and rural households also indicates that $\mathrm{CO}_{2}$ reduction technologies bring co-benefits on improving the $\mathrm{PM}_{2.5}$ pollution problem. 

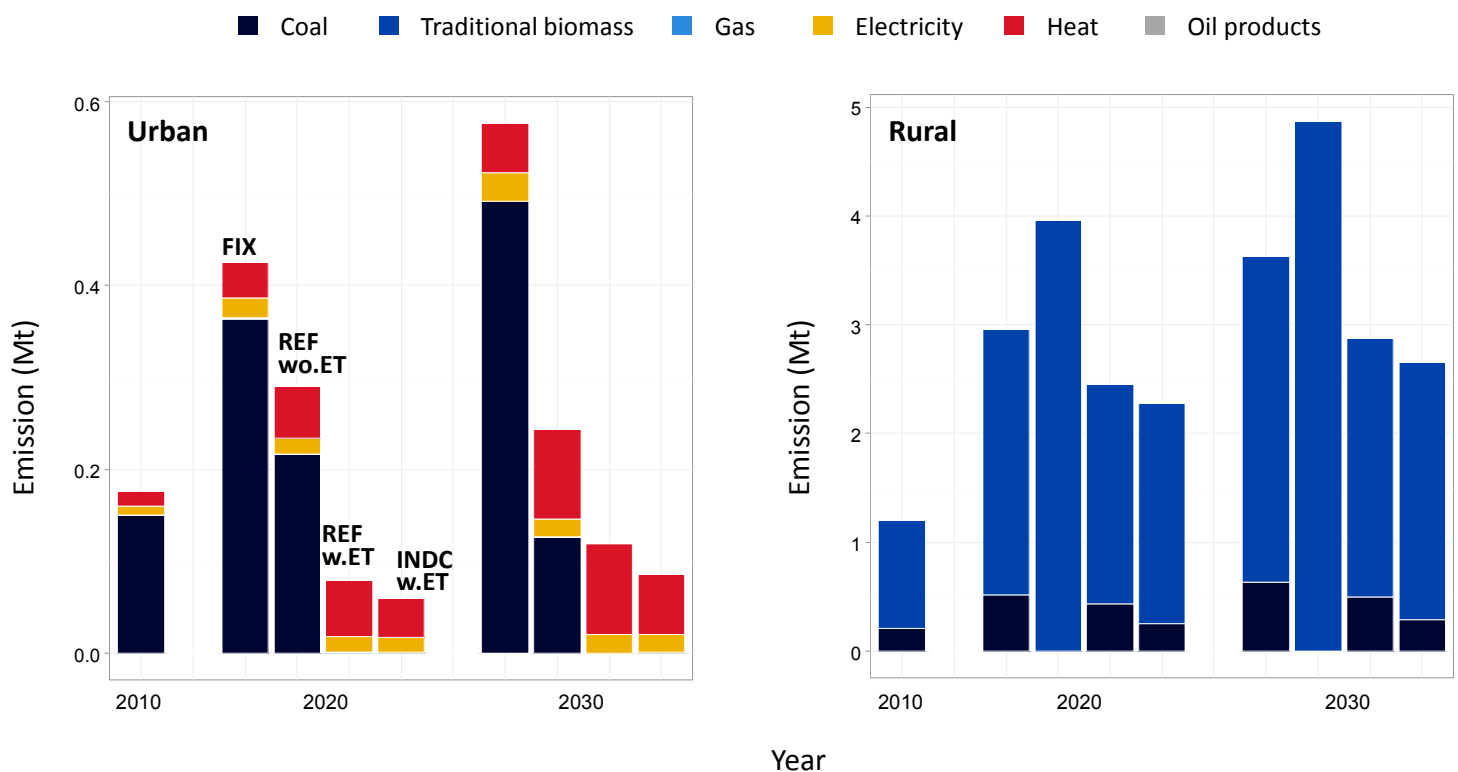

Figure 6. National Particulate Matter 2.5 Emissions (Model Projection).

Emission of non- $\mathrm{CO}_{2}$ emissions is also another important reason to consider energy transition while modeling energy systems. Taking $\mathrm{PM}_{2.5}$ emissions as an example, in rural household it is mainly caused by burning of traditional biomass. When using a cost optimization model such as AIM/Enduse to project future emission pathways without constrains on energy shares, model simulation will result in a large share of traditional biomass due to its low cost and the $\mathrm{CO}_{2}$ emissions factor. However, burning traditional biomass emits large amounts of $\mathrm{PM}_{2.5}$ and brings a high risk of indoor air pollution. Through introducing energy transition we are able to set a proper limitation of traditional biomass share in the future and effectively avoid this kind of risk.

\section{Conclusions}

In this study, we introduce the energy stack theory in the Chinese residential sector. Co-relations between 12 socioeconomic indicators and household energy choices are examined. Previous studies of India, Zimbabwe and South Africa suggested that income is an important monetary factor that effects energy transition. Through this study, we found that income also has a considerable impact on energy use in the Chinese households. On the other hand, several existing studies of Bolivia, Guatemala and some Asian countries suggested that gender perspective is an influencing factor of traditional biomass use in households. However, the results of this study suggest that female share and energy use are not co-related in the Chinese households.

Socioeconomic indicators are used to estimate the future household energy share in China. Energy consumption and gas emissions are estimated in scenarios with and without consideration of energy transition. The following four findings are observed from the results:

(1) Income and education are two major drivers of energy transition in the residential sector;

(2) Previous studies pointed out that female share in households has an impact on household energy choice in Bolivia, Guatemala and some Asian countries. However, in China, this co-relation is not found.

(3) Coal is expected to be phased out during the next decade in urban China but will still retain a certain share in rural China.

(4) Without considering energy transition, there is an overestimation of coal share in urban China, and an underestimation of coal share in rural China, which furthermore affects the $\mathrm{CO}_{2}$ emissions estimations in the future. 
(5) Overestimation or underestimation of a certain energy use not only effects $\mathrm{CO}_{2}$ emissions estimations but also $\mathrm{PM}_{2.5}$ in REF wo.ET (a reference without considering energy transition constraints).

Acknowledgments: This research was supported by the Environment Research and Technology Development Fund (S-12-2) of the Ministry of the Environment, Japan. The Found covers the costs to publish in open access.

Author Contributions: Rui Xing, Tatsuya Hanaoka, Yuko Kanamori and Toshihiko Masui conceived and designed the research; Rui Xing collected the data and conducted the regression analysis and model simulation. Tatsuya Hanaoka, Yuko Kanamori and Toshihiko Masui supervised the data collection and data analysis, and verified the results. Rui Xing drafted the manuscript. Tatsuya Hanaoka, Yuko Kanamori and Toshihiko Masui reviewed, commented on, and edited the manuscript.

Conflicts of Interest: The authors declare no conflict of interest. The founding sponsors had no role in the design of the study; in the collection, analyses, or interpretation of data; in the writing of the manuscript, or in the decision to publish the results.

\section{Appendix A}

Table A1 summarizes the data sources and time span of regression analysis.

Table A1. Data sources of regression analysis.

\begin{tabular}{lll}
\hline Variable & Reference & Time Span \\
\hline $\begin{array}{l}\text { Income, education, household size, } \\
\text { per capita floor area, dependency, } \\
\text { cereal production share, timber } \\
\text { production share, coal production } \\
\text { dummy, female share }\end{array}$ & $\begin{array}{l}\text { China Statistical } \\
\text { Yearbook [54] }\end{array}$ & \multirow{2}{*}{ 2000-2007 } \\
\cline { 1 - 2 } HDD18 & $\begin{array}{l}\text { China Meteorological } \\
\text { Data Service Center [55] }\end{array}$ & \\
\cline { 1 - 2 } $\begin{array}{l}\text { Energy share (stalks, firewood, } \\
\text { coal, LPG, electricity) }\end{array}$ & $\begin{array}{l}\text { China Energy Statistical } \\
\text { Yearbook [56] }\end{array}$ & \\
\hline
\end{tabular}

\section{Appendix B}

Table A2 shows the IEA's projection of primary energy share in electricity generation of China.

Table A2. China: Current policies' scenario.

\begin{tabular}{ccccccc}
\hline & \multicolumn{2}{c}{2020} & \multicolumn{2}{c}{$\mathbf{2 0 3 0}$} & \multicolumn{2}{c}{$\mathbf{2 0 4 0}$} \\
\hline & TWh & $\%$ & TWh & $\%$ & TWh & $\%$ \\
Total production & $7,348,000$ & 1.00 & $9,970,000$ & 1.00 & $12,024,000$ & 1.00 \\
Coal & $4,778,000$ & 0.65 & $6,146,000$ & 0.62 & $7,296,000$ & 0.61 \\
Oil & 7000 & 0.00 & 6000 & 0.00 & 4000 & 0.00 \\
Gas & 306,000 & 0.04 & 580,000 & 0.06 & 779,000 & 0.06 \\
Biofuels & 173,000 & 0.02 & 272,000 & 0.03 & 337,000 & 0.03 \\
Waste & 0 & 0.00 & 0 & 0.00 & 0 & 0.00 \\
Nuclear & 400,000 & 0.05 & 792,000 & 0.08 & $1,003,000$ & 0.08 \\
Hydro & $1,180,000$ & 0.16 & $1,358,000$ & 0.14 & $1,490,000$ & 0.12 \\
Geothermal & 1000 & 0.00 & 3000 & 0.00 & 8000 & 0.00 \\
Solar PV & 116,000 & 0.02 & 196,000 & 0.02 & 267,000 & 0.02 \\
Solar thermal & 2000 & 0.00 & 5000 & 0.00 & 16,000 & 0.00 \\
Wind & 385,000 & 0.05 & 612,000 & 0.06 & 822,000 & 0.07 \\
Tide & 0 & 0.00 & 0 & 0.00 & 2000 & 0.00 \\
Others resources & 0 & 0.00 & 0 & 0.00 & 0 & 0.00 \\
\hline
\end{tabular}




\section{Appendix C}

Figure A1 indicates the regional income and education level in base year (2010) and target year (2030).
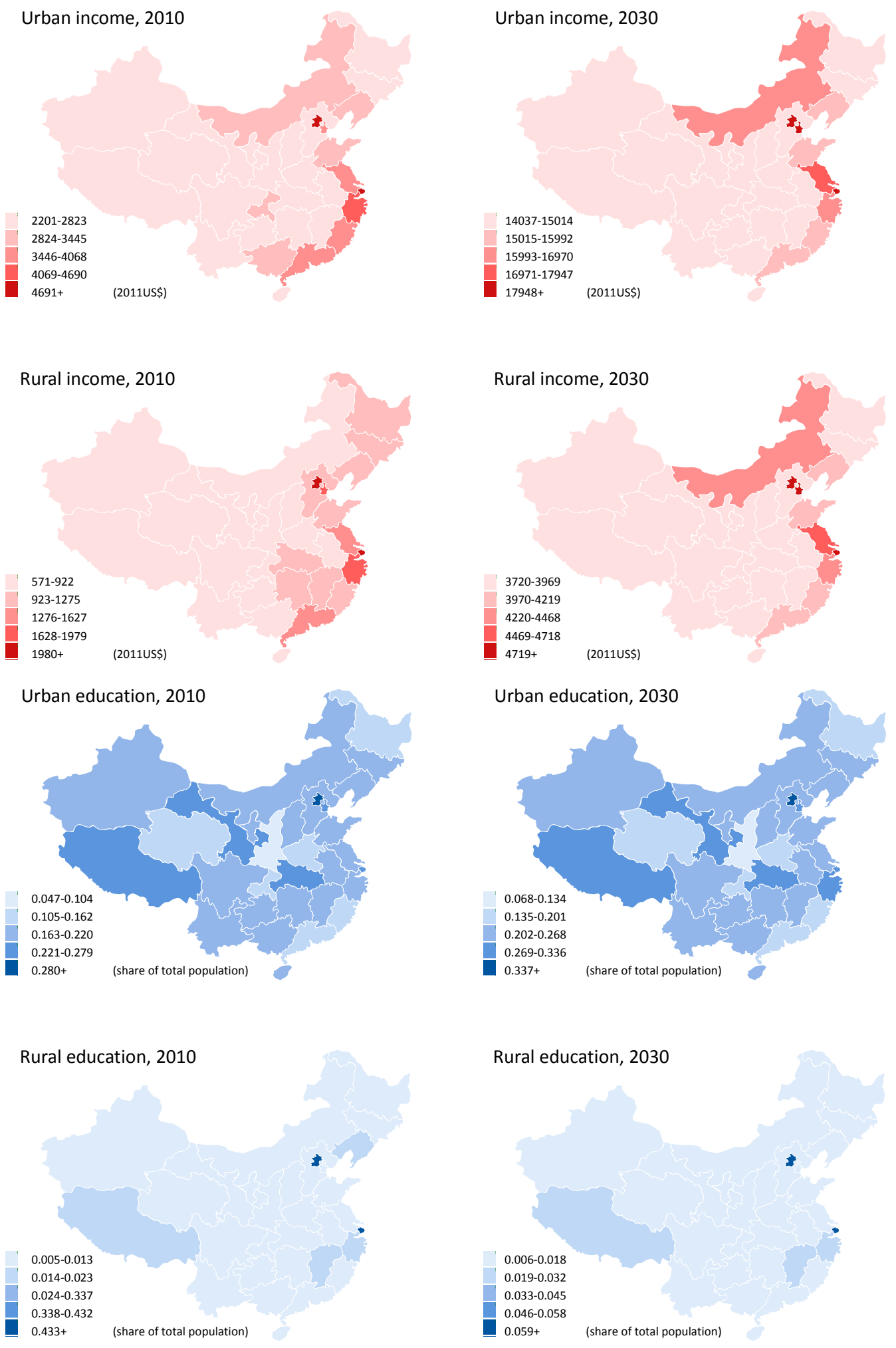

Figure A1. Regional income and education level. 


\section{References}

1. IEA statistics. Available online: http://www.iea.org/statistics/statisticssearch/report/?country=CHINA\& product=balances\&year=2000 (accessed on 24 February 2017).

2. Van der Kroon, B.; Brouwer, R.; Van Beukering, P.J.H. The energy ladder: Theoretical myth or empirical truth? Results from a meta-analysis. Renew. Sustain. Energy Rev. 2013, 20, 504-513. [CrossRef]

3. Guan, D.; Liu, Z.; Geng, Y.; Lindner, S.; Hubacek, K. The gigatonne gap in China's carbon dioxide inventories. Nat. Clim. Chang. 2012, 2, 672-675. [CrossRef]

4. Zhou, N.; Fridley, D.; McNeil, N.; Zheng, N.; Ke, J.; Levine, M. China's Energy and Carbon Emissions Outlook to 2050. Available online: https: / / china.lbl.gov/sites/all/files/lbl-4472e-energy-2050april-2011.pdf (accessed on 6 February 2017).

5. Barnes, D.F.; Floor, W.M. Rural energy in developing countries: A challenge for economic development. Annu. Rev. Energy Environ. 1996, 21, 497-530. [CrossRef]

6. Peng, W.; Hishamb, Z.; Pan, J. Household level fuel switching in rural Hubei. Energy Sustain. Dev. 2010, 14, 238-244. [CrossRef]

7. Gupta, G.; Kohlin, G. Preferences for domestic fuel: Analysis with socioeconomic factors and rankings in Kolkata, India. Ecol. Econ 2006, 57, 107-121. [CrossRef]

8. Sathaye, J.; Tyler, S. Transitions on household energy use urban China, India, the Philippines, Thailand and Hong Kong. Annu. Rev. Energy Environ. 1991, 16, 295-335. [CrossRef]

9. Israel, D. Fuel choice in developing countries: Evidence from Bolivia. Econ Dev. Cult. Chang. 2002, 50, 865-890. [CrossRef]

10. Heltberg, R. Factors determining household fuel choice in Guatamala. Environ. Dev. Econ. 2005, 10, 337-361. [CrossRef]

11. Masera, O.R.; Saatkamp, B.D.; Kammen, D.M. From linear fuel switching to multiple cooking strategies: A critique and alternative to the energy ladder model. World Dev. 2000, 28, 2083-2103. [CrossRef]

12. Arnold, J.E.M.; Kohlin, G.; Persson, R. Woodfuels, livelihoods, and policy interventions: Changing perspectives. World Dev. 2006, 34, 596-611. [CrossRef]

13. Maconachiea, R.; Tankob, A.; Zakariyac, M. Descending the energy ladder? Oil price shocks and domestic fuel choices in Kano, Nigeria. Land Use Policy 2009, 26, 1090-1099. [CrossRef]

14. Wickramasinghe, A. Energy access and transition to cleaner cooking fuels and technologies in Sri Lanka: Issues and policy limitations. Energy Policy 2011, 39, 7567-7574. [CrossRef]

15. Hosier, R.H.; Kipondya, W. Urban household energy use in Tanzania: prices, substitutes and poverty. Energy Policy 1993, 21, 454-473. [CrossRef]

16. Hiemstra-van der Horst, G.; Hovorka, A.J. Reassessing the "energy ladder": Household energy use in Maun, Botswana. Energy Policy 2008, 36, 3333-3344. [CrossRef]

17. Hosier, R.H.; Dowd, J. Household fuel choice in Zimbabwe: An empirical test of the energy ladder hypothesis. Resour. Energy 1987, 9, 347-361. [CrossRef]

18. Farsi, M.; Filipini, M.; Pachauri, S. Fuel choices in urban Indian households. Environ. Dev. Econ. 2007, 12, 757-774. [CrossRef]

19. Davis, M. Rural household energy consumption: The effects of access to electricity—Evidence from South Africa. Energy Policy 1998, 26, 207-217. [CrossRef]

20. Zhao, C.-S.; Niu, S.-W.; Zhang, X. Effects of household energy consumption on environment and its influence factors in rural and urban areas. Energy Procedia 2012, 14, 805-811.

21. Kainuma, M.; Matsuoka, Y.; Morita, T. Climate Policy Assessment: Asia-Pacific Integrated Modeling; Springer: Tokyo, Japan, 2003.

22. Hanaoka, T.; Masui, T.; Matsuoka, Y.; Hibino, G.; Fujiwara, K.; Motoki, Y.; Oshiro, K. AIM/Enduse Model Manual. AIM Interim Report. Available online: http://www-iam.nies.go.jp/aim/data_tools/enduse_ model/aim_enduse_manual.pdf (accessed on 6 March 2017).

23. Xing, R.; Hanaoka, T.; Kanamori, Y.; Dai, H.; Masui, T. An impact assessment of sustainable technologies for the Chinese urban residential sector at provincial level. Environ. Res. Lett. 2015, 10. [CrossRef]

24. Cooke, P.; Kohlin, G.; Hyde, W. Fuel wood, forests and community management evidence from household studies. Environ. Dev. Econ. 2008, 13, 103-135. [CrossRef] 
25. Wang, X.; Feng, Z. Rural household energy consumption in Yangzhong county of Jiangsu province in China. Energy 1996, 22, 1159-1162.

26. Ning, Y.; Li, Y.; Ding, T.; Tonooka, Y. A survey on energy consumption in rural households in north-east China. Sustain. Energy 2012, 2, 76-81. (In Chinese)

27. Han, Y.; Wang, D.; Bi, Y. Analysis on current situation of rural household energy consumption in Tancheng county. Chin. Agric. Sci. Bull. 2013, 29, 182-187. (In Chinese)

28. Luo, G.; Zhang, Y. Analysis on rural energy consumption of China. Chin. Agric. Sci. Bull. 2008, 24, 535-540. (In Chinese)

29. Zhou, S.D.; Cui, Q.F.; Wang, C.C. Study on the Quantity, Structure and Influencing Factors of Rural Household Energy Consumption: A Case Study in Inner Mongolia. Resour. Sci. 2009, 31, 696-702. (In Chinese)

30. Van Vuuren, D.P.; Riahi, K.; Moss, R.; Edmonds, J.; Thomson, A.; Nakicenovic, N.; Kram, T.; Berkhout, F.; Swart, R.; Janetos, A.; et al. A proposal for a new scenario framework to support research and assessment in different climate research communities. Globl. Environ. Chang. 2012, 22, 31-35. [CrossRef]

31. O’Neill, B.C.; Kriegler, E.; Ebi, K.L.; Kemp-Benedict, E.; Riahi, K.; Rothman, D.S.; van Ruijven, B.J.; van Vuuren, D.P.; Birkmann, J.; Kok, K.; et al. The roads ahead: Narratives for shared socioeconomic pathways describing world futures in the 21st century. Globl. Environ. Chang. 2015. [CrossRef]

32. Xing, R.; Hanaoka, T.; Kanamori, Y.; Masui, T. Mitigation Potentials in the Chinese Commercial Sector at Provincial Level up to 2030. In Proceedings of the 12th Biennial International Conference on EcoBalance, Kyoto, Japan, 3-6 October 2016.

33. IEA (International Energy Agency). World Energy Outlook 2016; International Energy Agency: Paris, France, 2016.

34. REAS. Regional Emission Inventory in Asia Database. Available online: http://www.nies.go.jp/REAS/ (accessed on 29 February 2016).

35. EEA (European Environment Agency). EMEP/EEA Air Pollutant Emission Inventory Guidebooks-2009; European Environment Agency: København, Denmark, 2009.

36. EEA, European Environment Agency. EMEP/EEA Air Pollutant Emission Inventory Guidebooks-2013; European Environment Agency: København, Denmark, 2013.

37. The Intergovernmental Panel on Climate Change. IPCC Guideline for National Greenhouse Gas Inventories; Cambridge University Press: Cambridge, UK, 2006.

38. Klimont, Z.; Cofala, J.; Xing, J.; Wei, W.; Zhang, C.; Wang, S.; Kejun, J.; Bhandari, P.; Mathur, R.; Pupohit, P.; et al. Projections of $\mathrm{SO}_{2}, \mathrm{NOx}$ and carbonaceous aerosols emissions in Asia. Tellus B 2009, 61, 602-617. [CrossRef]

39. Zhao, Y.; Nielsen, C.P.; Lei, Y.; McElroy, M.B.; Hao, J. Quantifying the uncertainties of a bottom-up emission inventory of anthropogenic atmospheric pollutants in China. Atmos. Chem. Phys. 2011, 11, 2295-2308. [CrossRef]

40. Qin, Y.; Xie, S.D. Spatial and temporal variation of anthropogenic black carbon emissions in China for the period 1980-2009. Atmos. Chem. Phys. 2012, 12, 4825-4841. [CrossRef]

41. Streets, D.G.; Bond, T.C.; Lee, T.; Jang, C. On the future of carbonaceous aerosol emissions. J. Geophys. Res. 2004, 109. [CrossRef]

42. Cao, G.; Zhang, X.; Zheng, F. Inventory of black carbon and organic carbon emissions from China. Atmos. Environ. 2006, 40, 6516-6527. [CrossRef]

43. Zhang, Q.; Streets, D.G.; Carmichael, G.R.; He, K.; Huo, H.; Kannari, A.; Klimont, Z.; Park, I.; Reddy, S.; Fu, J.S.; et al. Asian emissions in 2006 for the NASA INTEX-B mission. Atmos. Chem. Phys. 2009, 9, 5131-5153. [CrossRef]

44. Wei, W.; Wang, S.; Chatani, S.; Klimont, Z.; Cofala, J.; Hao, J. Emission and speciation of non-methane volatile organic compounds from anthropogenic sources in China. Atmos. Environ. 2008, 42, 4976-4988. [CrossRef]

45. IIASA (International Institute for Applied Systems Analysis). GAINS ASIA: Scenarios for Cost-Effective Control of Air Pollution and Greenhouse Gases in China; International Institute for Applied Systems Analysis: Laxenburg, Austria, 2008.

46. NDRC (National Development \& Reform Commission of China). China's Intended Nationally Determined Contribution: Enhanced Actions on Climate Change; National Development \& Reform Commission of China: Beijing, China, 2015. 
47. IEA (International Energy Agency). $\mathrm{CO}_{2}$ Emission from Fuel Combustion, 2015; International Energy Agency: Paris, France, 2015.

48. IEA (International Energy Agency). Energy Balances of Non-OECD Countries, 2015; International Energy Agency: Paris, France, 2015.

49. World Bank. $\mathrm{CO}_{2}$ emissions. Available online: http://data.worldbank.org/indicator/EN.ATM.CO2E.PP.GD (accessed on 6 March 2017).

50. Liu, Z. China's Carbon Emission Report 2015; Harvard Kennedy School: Cambridge, MA, USA, 2015.

51. China Nengyuan.com. Available online: http://www.china-nengyuan.com/product/86715.html (accessed on 23 February 2017).

52. United Nations, the Paris Agreement. In Proceedings of the United Nations Framework Convention on Climate Change, Paris, France, 2015; Available online: http:/ / unfccc.int/files/essential_background/ convention/application/pdf/english_paris_agreement.pdf (accessed on 6 March 2017).

53. National Bureau of Statistical of China (NBSC). Publication Database; National Bureau of Statistical of China: Beijing, China, 2017. Available online: http://www.stats.gov.cn/tjsj/ndsj/2016/indexch.htm (accessed on 24 February 2017).

54. National Bureau of Statistical of China (NBSC). Publication Database; National Bureau of Statistical of China: Beijing, China. Available online: http:/ / data.stats.gov.cn/publish.htm?sort=1 (accessed on 14 April 2017).

55. National Meteorological Information Center of China, China Meteorological Data Service Center, China. Available online: http:/ / data.cma.cn/en (accessed on 14 April 2017).

56. National Bureau of Statistical of China (NBSC). China Energy Statistical Yearbook (2001-2008); China Statistics Press: Beijing, China, 2001-2008.

(C) 2017 by the authors. Licensee MDPI, Basel, Switzerland. This article is an open access article distributed under the terms and conditions of the Creative Commons Attribution (CC BY) license (http:/ / creativecommons.org/licenses/by/4.0/). 